\title{
Pengembangan Aplikasi Kuliah Kerja Nyata Pada IAIN Salatiga Dengan Metode Prototype
}

\author{
Agung Suprapto \\ Komunikasi Penyiaran Islam IAIN Salatiga \\ suprapto.agung@iainsalatiga.ac.id
}

\begin{abstract}
This time, the management of IAIN Salatiga Kuliah Kerja Nyata (KKN) program still used a conventional or traditional method to handle the student's document. The document was prepared manually, so it will need more time to finish. Another side, by conventional system have some problem. So, the aims of this research is to develop a new system that can help to solve the KKN management system in IAIN Salatiga. The KKN management system consists of registration database, management control lecturer, and reporting management system in KKN program. In this research, application development used prototype methods and BlackBox testing was done to validate the method. From the BlackBox testing, KKN program of IAIN Salatiga was implemented well. The usability value was obtained from learnability in amount $3.84 \%, 3.80 \%$ of efficiency, $3.97 \%$ of satisfaction, and $81.20 \%$ of advisability. Based on the percentage, it can be concluded that the software application is suitable to develop for IAIN Salatiga KKN program.
\end{abstract}

\section{Keyword: KKN, Prototype, IAIN Salatiga}

\section{Introduction (10 PT)}

Kuliah Kerja Nyata (KKN) merupakan maninfestasi pengimplementasian pendidikan melalui pengalaman belajar kepada mahasiswa di luar kampus dalam rangka mengidentifikasi secara langsung serta menangani permasalahan yang ada di tengah masyarakat [1]. Melalui program - program yang dilakukan oleh mahasiswa diharapkan dapat meningkatkan kualitas hidup masyarakat [2]. Tujuan utama dari kegiatan KKN yaitu melayani masyarakat, KKN mempunyai kontribusi penting untuk menyiapkan generasi mahasiswa yang berkualitas [3]. Menejemen Pengelolaan data dalam kegiatan KKN mulai dari menejemen data pendaftar, menejemen data kelompok dan Lokasi KKN, menejemen data dosen pembimbing (DPL), Pelaporan Kegiaran KKN sampai dengan pemberian Nilai KKN kepada mahasiswa oleh dosen pembimbing (DPL) membutuhkan dokumentasi data yang baik. Apabila proses kegiatan tersebut tidak dimenejemen dengan baik akan menimbukan banyak permasalahan.

IAIN Salatiga selama ini melaksanakan kegiatan KKN sebagai wujud pengabdian kepada masyarakat. IAIN Salatiga menjadikan KKN menjadi mata kuliah wajib yang harus diambil oleh mahasiswa, hal ini menunjukan bahwa komitmen IAIN Salatiga dalam menjadikan mahasiswa menjadi generasi yang berkualitas dengan melakukan pengabdian kepada masyarakat disuatu daerah. Dalam pelaksanaan kegiatan KKN yang ada pada IAIN Salatiga ditangani oleh suatu lembaga yaitu LP2M ( Lembaga Penelitian dan Pengabdian kepada Masyarakat ). Selama ini pengelolaan data Kuliah Kerja Nyata yang ada di LP2M IAIN Salatiga belum terkomputerisasi, pencatatan dan pengolahan data memakan waktu lama dan merepotkan bagi staf maupun pegawai LP2M IAIN Salatiga belum lagi data mahasiswa maupun DPL yang mengikuti kegiatan KKN yang harus di buat setiap tahunnya. Seringnya terjadi permasalahan dalam proses pengolahan laporan KKN menjadi motivasi untuk membangun aplikasi Kuliah Kerja Nyata berbasis digital. Diharapkan dengan adanya aplikasi kuliah kerja nyata secara online pekerjaan staf maupun pegawai sangatlah terbantu karena pengelolaan data dapat terselesaikan dengan mudah dan cepat serta lebih akurat.

Dalam pengembangannya metode yang digunakan adalah metode prototype. Dalam metode prototype Kesalah pahaman antara sistem developer dengan user dapat diketahui dan dibetulkan secara cepat. prototype yang sedang berjalan mungkin sangat berguna dalam suatu pembuktian manajemen sehingga mempu menjamin kesinambungan dukungan [4]. Selain itu Beberapa penelitian sejenis terkait Sistem Informasi kuliah kerja nyata yang pernah dilakukan sebelumnya. Fitra Kasma Putra dengan judul "Disain Database Untuk Pengelolaan Datakuliah Kerja Nyata (KKN) Pada Institut Agama Islam Negeri (IAIN) Batusangkar" menyimpulkan bahwa dengan di dapatnya suatu database yang baik dan benar oleh Lembaga Penelitian dan Pengabdian Masyarakat (LP2M) IAIN Batusangkar, maka LP2M akan mudahkan dalam 
mengelola mahasiswa yang akan mengikuti kegiatan KKN, meskipun yang akan mengikuti dalam jumlah yang banyak [5].

Dalam penelitian yang berjudul "Rancang Bangun Sistem Informasi Kuliah Kerja Nyata (KKN) Pada Universitas Muria Kudus" menerangkan bahwa untuk membantu kelancaran kegiatan KKN pada Universitas Muria Kudus diperlukan aplikasi pengelolaan data kegiatan KKN. Dengan adanya aplikasi tersebut diharapkan mampu meningkatkan kualitas pelayanan dalam pengelolaan KKN serta mempermudah proses layanan administrasi KKN menjadi lebih akurat dan cepat [6]. Dalam penelitian yang dilakukan oleh Refly Christian Mandag yang berjudul "Pengembangan Sistem Informasi Kuliah Kerja Terpadu (KKT) di Universitas Sam Ratulangi" menyebutkan bahwa dengan sistem infromasi kuliah kerja terpadu ini dapat membantu pekerjaan pegawai LP2M (Lembaga Penelitian dan Pengabdian kepada Masyarakat) Universitas Sam Ratulangi dalam penyampaian informasi, pembagian kelompok, dan penempatan lokasi KKT [7].

Penelitian yang dilakukan oleh Helfy Susilawati yang berjudul "Perancangan Aplikasi Kalkulator SParameter Berbasis Android" menjelaskan bahwa dalam pengembangan aplikasinya meggunakan metode prototype, serta dalam pengujuan aplikasi tersebut menggunakan Black Box testing yang berfokus pada pengujian persyaratan fungsional perangkat lunak, untuk mendapatkan serangkaian kondisi input yang sesuai dengan persyaratan fungsional suatu program [4]. Penelitian yang dilakukan oleh Veri Julianto dengan judul "Rancang Bangun Sistem Informasi Manajemen Bank Sampah Studi Kasus Pada Bank Sampah Panggung Berseri (BSPB)" menerangkan dalam pengembangan sistem infromasi menejemen ini metode yang digunakan adalah metode prototype. Metode prototype sering digunakan dalam sebuah project dimana pengguna masih belum memiliki konsep yang jelas terkait dengan kebutuhan dari sistem yang akan dibangun. Metode ini juga memiliki waktu yang cukup singkat [8].

\section{Metode Penelitian}

Prototyping merupakan model pengembangan aplikasi sederhana yang memberikan akses kepada pengguna memiliki konsep dasar tentang apikasi serta melakukan pengujian awal terhdapat aplikasi yang dibangun. Dalam metode ini pengembang dan pemakai saling berkomunikasi selama proses pembuatan, sehingga pengembang dapat dengan mudah memodelkan aplikasi yang dibangun [9]. Salah satu kunci keberhasilan dalam metode ini adalah pengembang dan penguna harus memiliki pemahaman bahwa prototype yang dibangun untuk mendefinisikan kebutuhan awal [10]. Berikut ini merupakan tahapan dalam Metode Prototype; (1) Communication, (2) Quick Plan, (3) Modelling Quick Design, (4) Construction, (5) Deployment, delivery \& feedback [11]

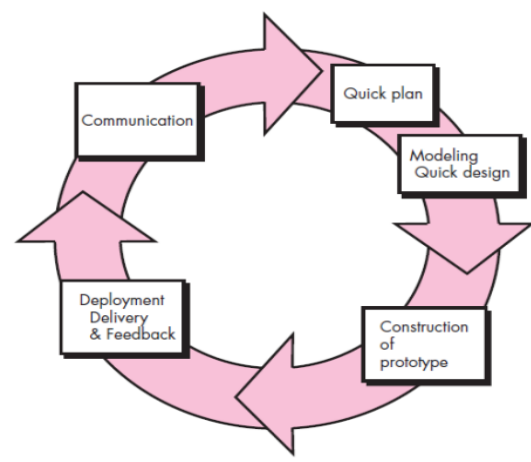

Gambar 1 Metode Prototype

\section{Hasil dan Analisis}

\subsection{Communication}

Selama ini pengelolaan data Kuliah Kerja Nyata yang ada di LP2M IAIN Salatiga belum terkomputerisasi, pencatatan dan pengolahan data memakan waktu yang cukup lama dan merepotkan bagi staf maupun pegawai LP2M IAIN Salatiga belum lagi data mahasiswa maupun DPL yang mengikuti kegiatan KKN yang harus di buat setiap tahunnya. Selain itu permasalahan secara umum yang di hadapai oleh IAIN Salatiga dalam pengelolaan Kegiatan KKN adalah proses administrasi yang masih berjalan secara manual sehingga rentan mengalami kesalahan dalam penulisan serta kehilangan data. Proses pelaporan kegiatan KKN yang membutuhkan waktu lama, dinilai kurang efisien dan efektif. Proses manualisasi yang berjalan belum mampu menyedikan informasi yang relevan dan aktual. 


\subsection{Quick Plan}

Tahapan dimana melakukan perencanaan strategis secara cepat dengan memberikan solusi atas identifikasi awal permasalahan. Melakukan kerja sama dengan pihak IAIN Salatiga lebih khususnya bagian LP2M untuk mengembangkan sebuah prototype aplikasi kuliah kerja nyata (KKN). Adapun hasil analisis sebagai berikut Perancangan aplikasi kuliah kerja nyata menggunakan bahasa php dan codeigniter sebagai freamworknya. aplikasi yang dikembangkan ini dapat sebagai sarana untuk menejemen data pendaftar, menejemen data kelompok dan Lokasi KKN, menejemen data dosen pembimbing (DPL), Pelaporan Kegiaran KKN sampai dengan pemberian Nilai KKN kepada mahasiswa.

\subsection{Modelling Quick Design}

Tahapan selanjutnya dari metode prototipe adalah modeling quick plan,dari tahapan-tahapan sebelumnya menjelaskan permasalahan dan peralatan yang harus dibutuhkan, tahapan ini menjelasakn perancangan dari aplikasi kuliah kerja nyata

\section{Diagram Konteks ( Contect Diagram )}

Diagram konteks merupakan diagram yang menggambarkan bagian besar dari aliran arus data aplikasi kuliah kerja nyata pada IAIN Salatiga, dapat dilihat pada gambar 2 di bawah ini

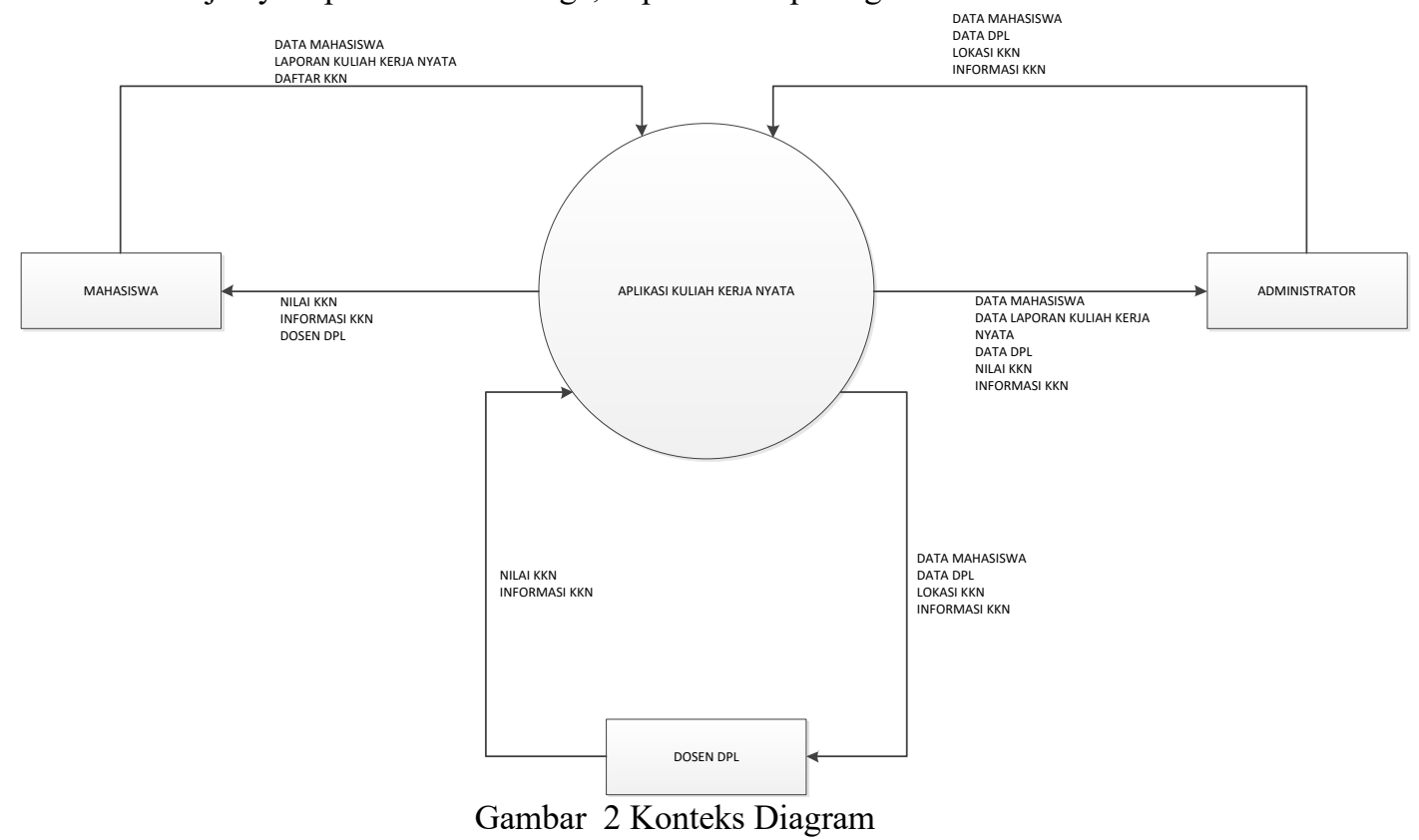

\section{Data Flow Diagram Level 1}

DFD Level 1 adalah Diagram yang menunjukkan semua proses utama yang menyusun keseluruhan dari aplikasi yang dibuat. Pada gambar 3 menunjukan proses DFD level 1 dari aplikasi kuliah kerja nyata yang dibangun. 


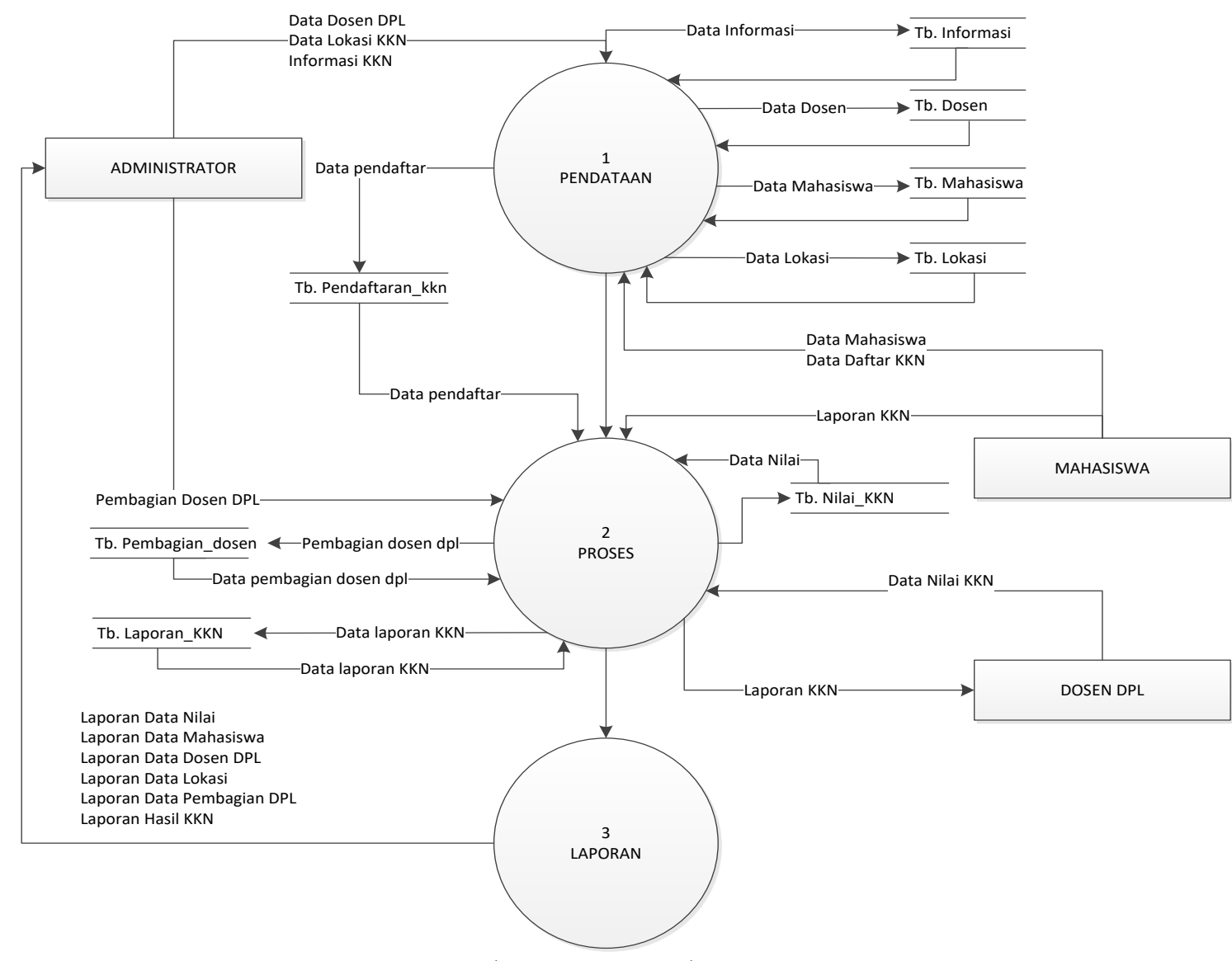

Gambar 3 DFD Level 1

\section{Construction}

Pada tahapan ini dilakukan pengkodean berdasarkan rancangan-rancangan yang telah dibuat

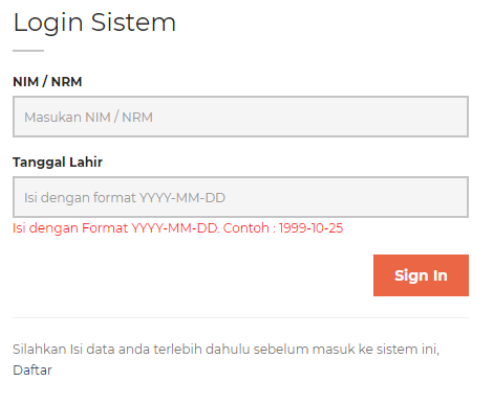

Gambar 4 Login Sistem

Pada gambar 4 merupakan desain dari Halaman login, pada halaman ini mahasiswa maupun dosen DPL bisa login dengan menggunakan username dan password yang sudah diberikan sebelumnya. Apabila berhasil login maka, sistem akan mengarahkan ke halaman dashboardnya masing - masing berdasarkan hak aksesnya. 

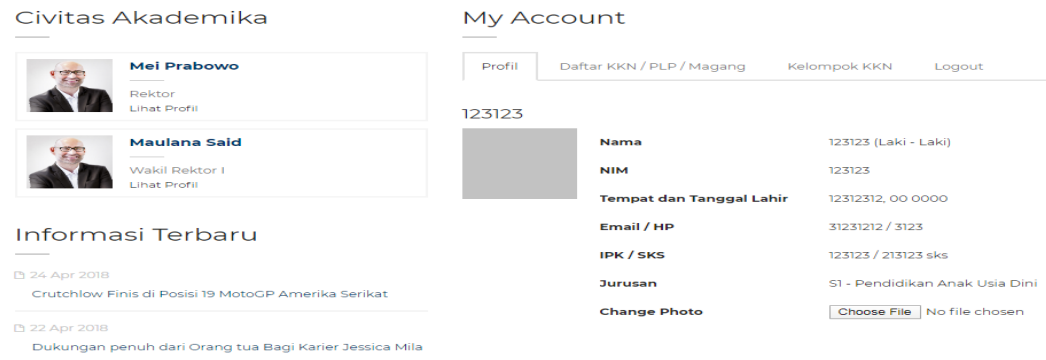

Gambar 5 Dashboard User

Gambar 5 Dashboard user merupakan dalama awal ketika user berhasil login ke sistem, setelah berhasil login mahasiswa dan dosen DPL akan diarahkan untuk melakukan pengupdate data diri mereka, dengan cara mengklik fungsi edit akun yang ada pada samping halaman.

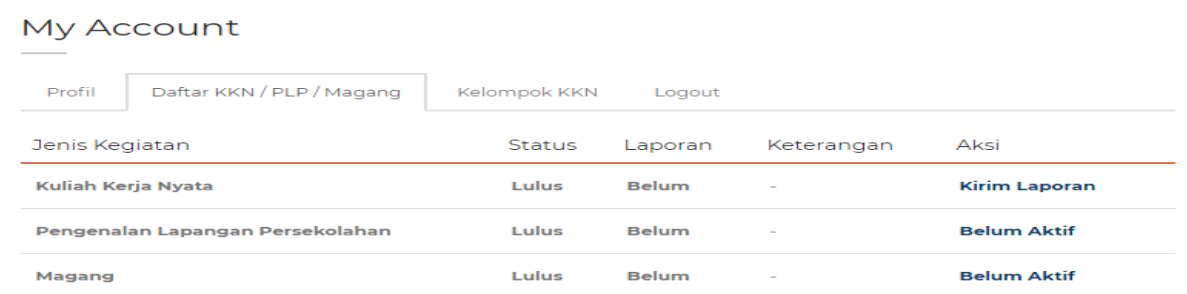

Gambar 6 Halaman Daftar KKN

Gambar 6 halaman daftar KKN merupakan dalam yang disediakan untuk mahasiswa dalam mendaftar KKN. Ketika mahasiswa tersebut berhasil login, selanjutnya mahasiswa bisa melakukan pendaftaran maupun mengetahui lokasi detail kelompok KKN. Pada gambar 7 Berikut ini merupakan halaman detail kelompok KKN yang sudah disetting oleh administrator.

\begin{tabular}{|c|c|c|c|c|}
\hline \multirow{2}{*}{$\begin{array}{l}\text { Profil } \\
\text { No. }\end{array}$} & \multicolumn{2}{|c|}{ Daftar KKN / PLP / Magang } & \multirow{2}{*}{$\begin{array}{c}\text { Kelompok KKN } \\
\text { Telp }\end{array}$} & \multirow{2}{*}{$\begin{array}{l}\text { Logout } \\
\qquad \text { Jurusan }\end{array}$} \\
\hline & NIM & Nama & & \\
\hline 1 & 13917155 & Sarjono & 3123 & S1 - Pendidikan Anak Usia Dini \\
\hline 2 & 13917190 & Maulana Said & 123123 & S1 - Pendidikan Anak Usia Dini \\
\hline 3 & 13917166 & Mei Prabowo & 088586837121 & S1 - Pendidikan Matematika \\
\hline 4 & 13917152 & MEI PRABOWO & 085867044024 & S1 - Pendidikan Anak Usia Dini \\
\hline
\end{tabular}

Gambar 7 Halaman Data Kelompok KKN

Dengan menggunakan portal ini mahasiswa juga bisa melaporkan hasil laporan kuliah kerja nyata nya. Berikut ini merupakan tampilan dari proses pelaporan hasil kuliah kerja nyata oleh mahasiswa.

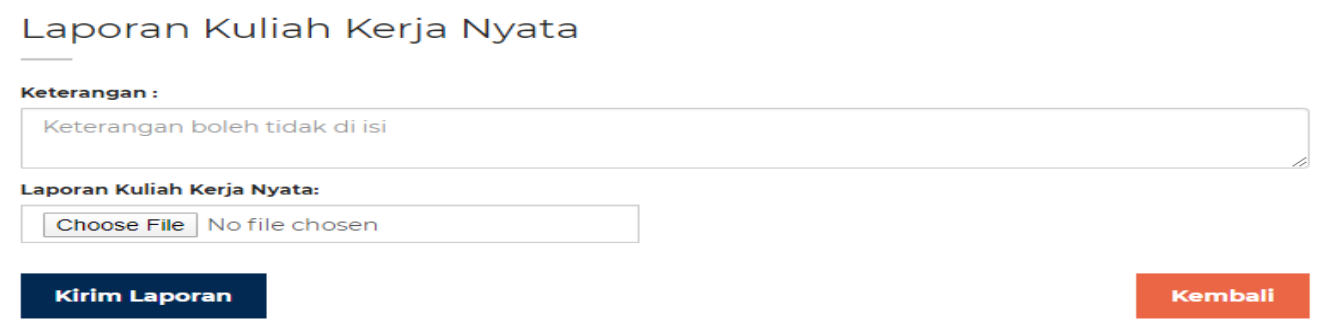

Gambar 8 Halaman Upload data Laporan KKN

Pada portal dosen DPL, dosen DPL memiliki dua menu utama yaitu daftar mahasiswa yang di bimbingnya serta laporan hasil Kuliah Kerja Nyata dari mahasiswa bimbingannya. Dengan portal ini 
dosen DPL bisa langsung melihat hasil laporan KKN serta memberikan nilai secara langsung. Berikut ini tampilan dari daftar mahasiswa bimbingan dari potal dosen DPL

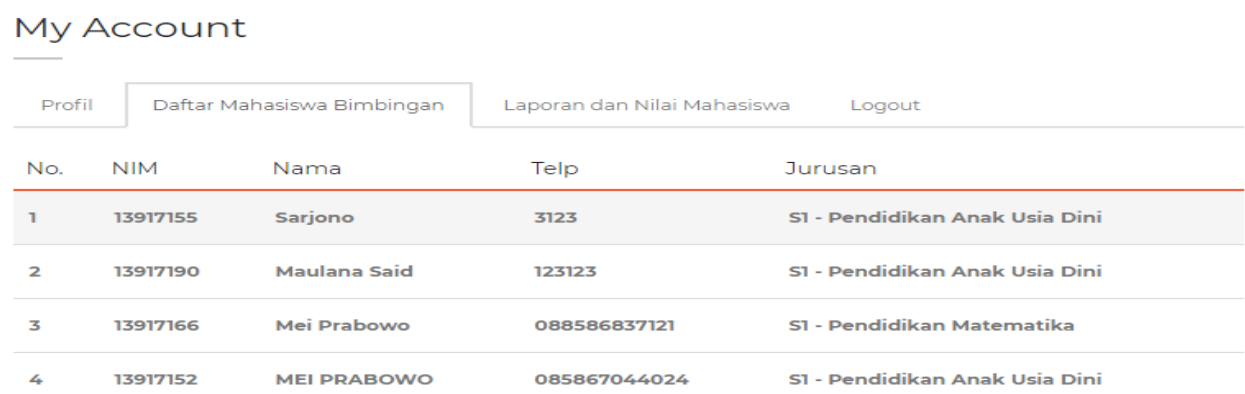

Gambar 9 Halaman Data Mahasiswa Bimbingan

\section{My Account}

\begin{tabular}{|c|c|c|c|c|c|c|c|c|c|}
\hline \multicolumn{2}{|c|}{ Profil } & \multicolumn{2}{|c|}{ Daftar Mahasiswa Bimbingan } & \multicolumn{2}{|c|}{ Laporan dan Nilai Mahasiswa } & \multicolumn{4}{|l|}{ Logout } \\
\hline No. & NIM & Nama & Telp & & Jurusan & & Laporan & Nilai & Aksi \\
\hline 1 & 13917155 & Sarjono & 3123 & & S1 - Pendidikan An: & Usia Dini & Laporan & 90 & Lihat \\
\hline 2 & 13917190 & Maulana Said & 123123 & & S1 - Pendidikan An: & Usia Dini & Laporan & 90 & Lihat \\
\hline 3 & 13917166 & Mei Prabowo & 08858 & 837121 & S1 - Pendidikan Ma & matika & Laporan & 90 & Lihat \\
\hline 4 & 13917152 & MEI PRABOWO & 0858 & 044024 & S1 - Pendidikan An & Usia Dini & Laporan & 90 & Lihat \\
\hline
\end{tabular}

Gambar 10 Halaman Upload Data Nilai

Dalam aplikasi kuliah kerja nyata ini, administrator aplikasi bertugas untuk mengelola seluruh data yang masuk baik dari mahasiswa maupun dari Dosen DPL. Administrator memiliki hak askses full akan aplikasi ini.

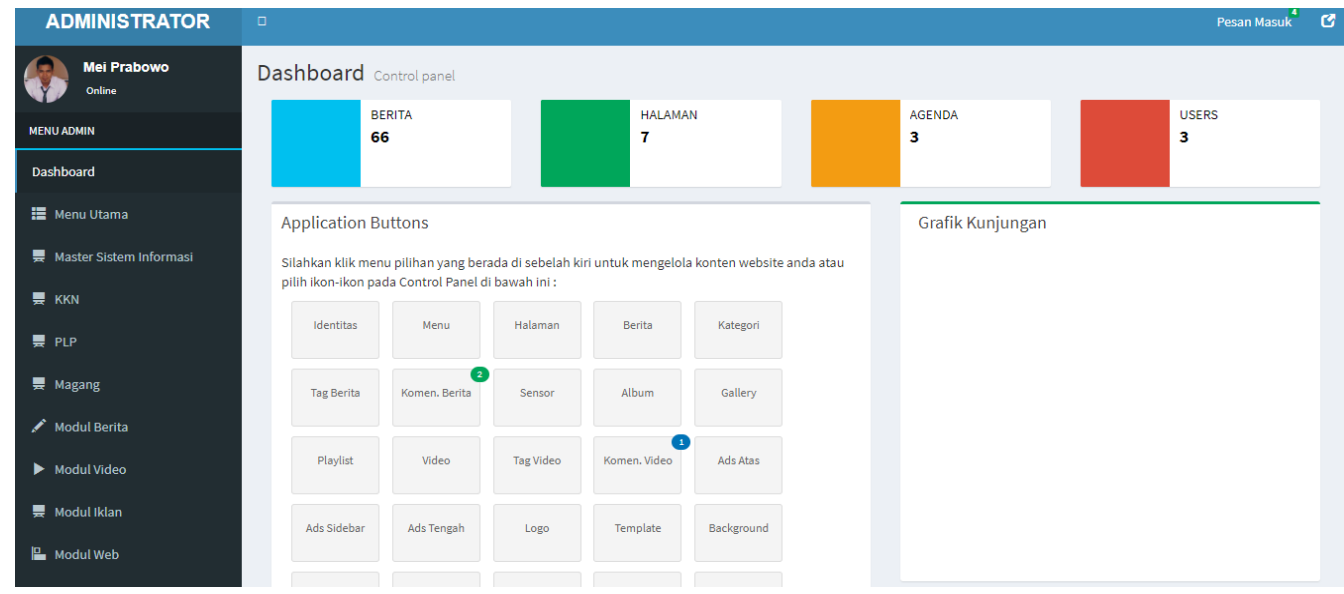

Gambar 11 Halaman Dashboard Administrator

\subsection{Deployment, delivery \& feedback}

Pada tahapan ini, program yang telah dibuat dilakukan pengujian untuk menguji fungsionalitas dari sistem yang dibuat. Pada penelitian ini, peneliti menggunakan pengujian black box testing [12]. Black Box Testing merupakan pengujian sistem yang berfokus pada spesifikasi fungsional dari perangkat lunak tersebut. Tester dapat mendefinisikan kumpulan kondisi input dan melakukan pengetesan pada spesifikasi fungsional program [13]. Hasil pada tahap testing disajikan pada Tabel berikut ini :

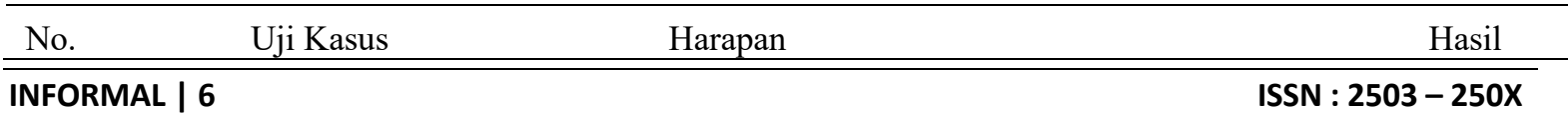




\begin{tabular}{|c|c|c|c|}
\hline & & & $\mathrm{OK}$ \\
\hline 1 & Daftar Kuliah Kerja Nyata & Mahasiswa Mengisi formulir KKN & $\mathrm{OK}$ \\
\hline 2 & Login System & Mahasiswa Berhasil masuk ke dashboard aplikasi & $\mathrm{OK}$ \\
\hline 3 & Upload Hasil KKN & Mahasiswa berhasil mengupload data hasil KKN ke aplikasi & $\mathrm{OK}$ \\
\hline 4 & Lihat Nilai & Mahasiswa Berhasil menlihat nilai yang diberikan oleh DPL & $\mathrm{OK}$ \\
\hline 5 & $\begin{array}{l}\text { Login DPL } \\
\text { Upload Data Nilai }\end{array}$ & $\begin{array}{l}\text { DPL Berhasil Login dan masuk ke dashboard aplikasi } \\
\text { DPL Mengisikan data nilai sesuai dengan yang di } \\
\text { bimbingnya }\end{array}$ & $\mathrm{OK}$ \\
\hline 7 & Login Administrator & $\begin{array}{l}\text { Administrator Berhasil masuk ke dashboard Administrator } \\
\text { Administrator melakukan pengisian data lokasi KKN serta }\end{array}$ & $\mathrm{OK}$ \\
\hline 8 & $\begin{array}{l}\text { Input Data Lokasi dan } \\
\text { DPL }\end{array}$ & $\begin{array}{l}\text { membagi DPL nya berdasarkan lokasi KKN nya sehingga } \\
\text { data tersimpan ke database }\end{array}$ & \\
\hline 9 & Input Informasi & $\begin{array}{l}\text { Administrator mengisikan informasi terkait KKN dan data } \\
\text { tersimpan } \\
\text { Fungsi Logout Berjalan dengan baik dan mengakhir session }\end{array}$ & $\mathrm{OK}$ \\
\hline 10 & Logout & loginnya & OK \\
\hline
\end{tabular}

Dari tabel tersebut dapat disimpulkan bawah aplikasi kuliah kerja nyata pada IAIN Salatiga dapat berjalan dengan baik. Selanjutnya dilakukan pengujian kepada pengguna aplikasi sebagai responden. Dalam hal ini pengujian aplikasi dilakukan oleh 30 responden. Tiap-tiap pertanyaan dari kuisioner tersebut bertujuan untuk menunjukkan tingkat usability menurut responden, dalam skala nilai 1- 5. USE adalah salah satu paket kuisioner non komersial yang bisa digunakan untuk penelitian usability system. Dalam kuisioner ini terdiri dari 10 pertanyaan yang mencakup nilai aspek-aspek usability [14].

Tabel 2. Kuesioner USE

\begin{tabular}{|c|c|c|c|c|c|c|}
\hline No. & Pernyataan & $\begin{array}{c}\text { STS } \\
1\end{array}$ & $\begin{array}{c}\text { TS } \\
2\end{array}$ & $\begin{array}{l}\mathrm{N} \\
3\end{array}$ & $\begin{array}{l}S \\
4\end{array}$ & $\begin{array}{c}\mathrm{SS} \\
5\end{array}$ \\
\hline \multicolumn{7}{|c|}{$\begin{array}{ll} & \text { Aspek Sistem ( System ) } \\
\end{array}$} \\
\hline 1 & Tampilan Aplikasi JKN mudah dikenali. & & & & & \\
\hline 2 & Aplikasi Mudah dioperasikan & & & & & \\
\hline 3 & Kombinasi warna enak di lihat & & & & & \\
\hline \multicolumn{7}{|c|}{ Aspek Pengguna ( User ) } \\
\hline 4 & Tempilan menu mudah di kenali & & & & & \\
\hline 5 & Fasilitas fungsi - fungsi berjalan dengan baik & & & & & \\
\hline 6 & Aplikasi mudah dibaca & & & & & \\
\hline 7 & Aplikasi mudah digunakan & & & & & \\
\hline 8 & Simbol - simbol mudah di pahami & & & & & \\
\hline \multicolumn{7}{|c|}{ Aspek Interaksi ( Interaction ) } \\
\hline 9 & Akses Informasi aplikasi mudah diperoleh & & & & & \\
\hline 10 & Aplikasi sesuai dengan kebutuhan & & & & & \\
\hline
\end{tabular}

Berdasarkan hasil usability testing tersebut di atas, maka diperoleh rekap nilai usability sebagai berikut :

Tabel 3. Hasil Kuesioner

\begin{tabular}{llc}
\hline No. & \multicolumn{1}{c}{ Pernyataan } & Hasil \\
\hline & \multicolumn{1}{c}{ Aspek Sistem ( System ) } \\
\hline 1 & Tampilan Aplikasi mudah dikenali. & 3,70 \\
2 & Aplikasi Mudah dioperasikan & 4,30 \\
3 & Kombinasi warna enak di lihat & 3,50 \\
\hline
\end{tabular}

Aspek Pengguna ( User ) 


\begin{tabular}{clc}
\hline No. & \multicolumn{1}{c}{ Pernyataan } & Hasil \\
\hline 4 & Tempilan menu mudah di kenali & 3,90 \\
5 & Fasilitas fungsi - fungsi berjalan dengan baik & 4,20 \\
6 & Aplikasi mudah dibaca & 4,60 \\
7 & Aplikasi mudah digunakan & 4,20 \\
8 & Simbol - simbol mudah di pahami & 3,60 \\
\hline \multicolumn{2}{c}{ Aspek Interaksi ( Interaction ) } \\
\hline 9 & Akses Informasi aplikasi mudah diperoleh & 4,20 \\
10 & Aplikasi sesuai dengan kebutuhan & 4,40 \\
\hline
\end{tabular}

Berdasarkan hasil pengujian Usability pada aplikasi ini didapatkan hasil rekap nilai sebagai berikut : Nilai Learnability dapat dilihat dari ratarata hasil aspek system sebesar 3,83, Nilai Efficiency (fungsi-fungsi produk dapat dengan cepat dipergunakan), dapat dilihat pada fasilitas sebesar 4,20. Nilai Satisfaction yaitu hasil keseluruhan aspek sebesar 4,06. Selain berdasarkan hasil rekap nilai tingkat usability dari aplikasi ini, selanjutnya diukur menggunakan Frekuensi relatif. Hasil perhitungan dibandingkan dengan table standar kelayakan sistem berikut ini [15] :

Tabel Standar Kelayakan Sistem

\begin{tabular}{ll}
\hline \multicolumn{1}{c}{ Angka (\%) } & \multicolumn{1}{c}{ Kategori } \\
\hline Angka $<21$ & Sangat Tidak Layak \\
Angka $\leq 21$ angka $<40$ & Tidak Layak \\
Angka $\leq 40$ angka $<60$ & Cukup \\
Angka $\leq 60$ angka $<80$ & Layak \\
Angka $\leq 80$ angka $\leq 100$ & Sangat Layak \\
\hline
\end{tabular}

Hasil perhitungan dari 30 responden adalah 1218, maka kelayakan dari sistem yang diperoleh adalah 81,20 $\%$. Nilai tersebut termasuk dalam kategori "Sangat Layak".

\section{Conclusion}

Berdasarkan hasil penelitian dan pembahasan mengenai pengembangan aplikasi kuliah kerja nyata pada IAIN Salatiga maka dapat disimpulkan sebagai berikut :

Dengan meggunakan Metode prototype ini memang sangat membutuhkan komitmen dari user akan keterlibatannya membangun sistem, sehingga hal ini bisa menjadi permasalahan ketika para stakeholder tidak dapat hadir dalam perbaikan prototipe sistem

Aplikasi Kuliah Kerja Nyata yang dikembangkan berdasarkan hasil pengujian Blackbox Testing menunjukan bahwa aplikasi kuliah kerja nyata pada IAIN Salatiga secara keseluruhan fungsionalitas dapat berjalan dengan baik.

Hasil Nilai Usability pada aplikasi ini Learnability sebesar 3,84, Efficiency sebesar 3,80, Satisfaction sebesar 3,97dan kelayakan dari aplikasi ini berdasarkan standar kelayakan sistem maka diperoleh sebesar $81,20 \%$.

\section{References}

[1] F. Anasari, A. Suyatno, and I. F. Astuti, "Sistem Pelaporan Terpadu Kuliah Kerja Nyata Berbasis Digital (Studi Kasus: Lembaga Pengabdian Kepada Masyarakat Universitas Mulawarman)," Inform. Mulawarman J. Ilm. Ilmu Komput., vol. 10, no. 1, p. 11, 2016, doi: 10.30872/jim.v10i1.18.

[2] S. Handayani and S. A. Saputera, "Pengaruh Persepsi Kemudahan Dan Persepsi Kemanfaatan Terhadap Penggunaan Sistem Kkn Online Dengan Pendekatan Tam,” J. Technopreneursh. Inf. Syst., vol. 2, no. 2, pp. 53-58, 2019, doi: 10.36085/jtis.v2i2.313.

[3] F. Aristoteles, Nur Efendi, Febi Eka Febriansyah, Wisnu Lukito, "SISTEM INFORMASI KULIAH KERJA NYATA (KKN) BERBASIS ANDROID UNIVERSITAS LAMPUNG," J. komputasi, vol. 6, no. 2, pp. 1-10, 2018.

[4] H. Susilawati and T. A. Wiharso, "Perancangan Aplikasi Kalkulator S-Parameter Berbasis Android," 
J. Algoritm., vol. 02, no. 42, pp. 116-125, 2019.

[5] F. K. Putra, "Disain Database Untuk Pengelolaan Data Kuliah Kerja Nyata (Kkn) Pada Institut Agama Islam Negeri (Iain) Batusangkar,” J. Simtika, vol. 2, no. 1, pp. 60-65, 2019.

[6] G. Fandatiar, S. Supriyono, and F. Nugraha, "Rancang Bangun Sistem Informasi Kuliah Kerja Nyata (Kkn) Pada Universitas Muria Kudus," Simetris J. Tek. Mesin, Elektro dan Ilmu Komput., vol. 6, no. 1, p. 129, 2015, doi: 10.24176/simet.v6i1.247.

[7] R. C. Mandag, A. S. M. Lumenta, and Y. D. . Rindengan, "Pengembangan Sistem Informasi Kuliah Kerja Terpadu (KKT) di Universitas Sam Ratulangi,” J. Tek. Inform., vol. 10, no. 1, 2017, doi: 10.35793/jti.10.1.2017.15375.

[8] H. Veri Julianto, Hendrik Setyo Utomo, "Rancang Bangun Sistem Informasi Manajemen Bank Sampah Studi Kasus Pada Bank Sampah Panggung Berseri (BSPB),” J. Resti, vol. 3, no. 3, pp. 395401, 2019.

[9] W. W. Widiyanto, “Analisa Metodologi Pengembangan Sistem Dengan Perbandingan Model Perangkat Lunak Sistem Informasi Kepegawaian Menggunakan Waterfall Development Model, Model Prototype, Dan Model Rapid Application Development (Rad),” J. Inf., vol. 4, no. 1, pp. 34 40, 2018, [Online]. Available:

http://www.informa.poltekindonusa.ac.id/index.php/informa/article/view/34.

[10] D. Purnomo, "Model Prototyping Pada Pengembangan Sistem Informasi," J. Inform. Merdeka Pasuruan, vol. 2, no. 2, pp. 54-61, 2017.

[11] F. S. Handayani and M. P. Putri, "Implementasi Metode Prototipe Pada Website Penelusuran Minat Peserta Didik Sebagai Layanan Bimbingan Konseling," CSRID (Computer Sci. Res. Its Dev. Journal), vol. 10, no. 1, p. 44, 2018, doi: 10.22303/csrid.10.1.2018.44-57.

[12] T. Q. Fadillah, T. Suratno, U. Jambi, U. Jambi, and U. Jambi, "RANCANG BANGUN SISTEM INFORMASI ADMINISTRASI TAHANAN DAN BARANG BUKTI MENGGUNAKAN MODEL PROTOTYPE PADA KEPOLISIAN DAERAH JAMBI Tisya,” J. Sains dan Sist. Inf., vol. 2, no. 1, pp. 36-44, 2019.

[13] Y. Sutanto and A. Utomo, "PENGUJIAN APLIKASI WEBSITE MENGGUNAKAN BLACK BOX TESTING BOUNDARY VALUE ANALYSIS (Studi Kasus : Aplikasi website praktekdokter),” J. SAINSTECH Politek. Indonusa Surakarta, vol. 5, no. 2, pp. 52-57, 2018.

[14] B. O. Lubs, A. Salim, and Jefi, "Evaluasi Usability Sistem Aplikasi Mobile Jkn Menggunakan Use Questionnaire,” J. Saintekom, vol. 10, no. 1, pp. 65-76, 2020.

[15] G. I. Marthasari and N. Hayatin, “Analisis Usability Terhadap Sistem Lective Gegulang Berbasis USE Qestionnaire,” J. Semin. Nas. Teknol. dan Rekayasa, vol. 1, no. 1, pp. 1-8, 2017, [Online]. Available: http://research-report.umm.ac.id/index.php/sentra/article/view/1458. 